\title{
Does Consumption Lag Behind Incomes?
}

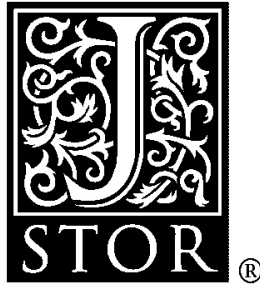

\section{J. Tinbergen}

The Review of Economic Statistics, Vol. 24, No. 1. (Feb., 1942), pp. 1-8.

Stable URL:

http://links.jstor.org/sici?sici=0034-6535\%28194202\%2924\%3A1\%3C1\%3ADCLBI\%3E2.0.CO\%3B2-5

The Review of Economic Statistics is currently published by The MIT Press.

Your use of the JSTOR archive indicates your acceptance of JSTOR's Terms and Conditions of Use, available at

http://www.jstor.org/about/terms.html. JSTOR's Terms and Conditions of Use provides, in part, that unless you have obtained prior permission, you may not download an entire issue of a journal or multiple copies of articles, and you may use content in the JSTOR archive only for your personal, non-commercial use.

Please contact the publisher regarding any further use of this work. Publisher contact information may be obtained at http://www.jstor.org/journals/mitpress.html.

Each copy of any part of a JSTOR transmission must contain the same copyright notice that appears on the screen or printed page of such transmission.

JSTOR is an independent not-for-profit organization dedicated to and preserving a digital archive of scholarly journals. For more information regarding JSTOR, please contact support@jstor.org. 


\section{The Review of Economic Statistics}

Volume XXIV

FEBRUARY, 1942

Number 1

\section{DOES CONSUMPTION LAG BEHIND INCOMES?}

\section{RELATION BETWEEN INCOME AND CONSUMPTION}

$\mathrm{T}$ HE fact that consumption outlay of individuals as well as of groups of individuals depends on their income is well known. Although this statement will hardly be doubted, it may be tested statistically from family budget statistics, as has been done by various investigators. These statistics can show only that consumption outlay by different people, having different incomes at the same moment, depends on income. Consumption outlay by the same family in different years, showing varying income, will not necessarily depend on income in the same way that is shown by family budget statistics.

This latter relation plays a highly important rôle in the causation of business cycles, a fact perhaps most stressed by Mr. Keynes, who created the term "propensity to consume" and who used this notion in various deductions. The importance of the propensity to consume for the quantitative approximation of some business-cycle problems has led a number of authors to measurements of that coefficient.

How large the propensity to consume may be is not the only important question. Another question is "What lag exists between income changes and changes in consumption outlay?" The longer this lag, the more slowly will the economic system react to changes in income and the longer, other things being equal, will be the process of adjustment (e.g., a business cycle).

The answer to this question - put by Mrs. Gilboy in this Review ${ }^{1}$ - cannot be given by family budget data, as already stated. The only possible method of securing an answer is by use of time series. The use of time series, however, always implies the difficulty that a number of ceteris paribus clauses are no longer fulfilled. Not only changes in income are the causes of any given changes in consumption outlay; other

\footnotetext{
${ }^{1}$ Elizabeth W. Gilboy, "Income-Expenditure Relations," this Review, xxiI (1940), pp. II 5-2I.
}

factors that also influence consumption outlay may have changed. A discussion of the most important of these other factors has been presented by Dr. Polak in this Review, ${ }^{2}$ where he applied the use of time series to consumption fluctuations in the United States during the period I9I9-32. The same method that he employed was used in an investigation of United Kingdom data, I870-1910, of which the present paper is a short account. Because of the nature of the statistical material available, one difference between the two studies lies in the choice of variables. This difference will be treated below (p. 5).

CONSUMPTION DATA, U. K., 1870-1910

The figures on which our calculations are based are of moderate quality only. The period and country under discussion, however, provide in so many respects a classical case for business-cycle research that experimenting with the material seemed worth while. Details of the calculation are shown in Table $\mathrm{I}$.

Hoffmann's index of industrial production ${ }^{3}$ seems to be the best index that can be constructed from the statistical material at hand. For the period that we are discussing, the index covers about two-thirds of total industrial production. For such important industries as cotton and wool spinning and for some smaller industries, data on consumption of raw materials have been used. For most of the other industries, net imports of raw materials only were available, which means that additions to raw-material stocks both by dealers and by industrial entrepreneurs have been included. We have tried to make a correction for this drawback (see p. 5 below).

${ }^{2}$ J. J. Polak, "Fluctuations in United States Consumption, I9r9-I932," this Review, XXI (I939), pp. I-I2.

${ }^{3}$ Walther Hoffmann, "Wachstum und Wachstumsformen der englischen Industriewirtschaft von I 700 bis zur Gegenwart," Probleme der Weltwirtschaft (Schriften des Instituts für Weltwirtschaft an der Universität Kiel, Nr. 63, Jena, I940). 
Table i. - Calculation of Consumption and Production

(Series 3, 6, 14, I5, and I6 rounded off to ten units.)

\begin{tabular}{|c|c|c|c|c|c|c|c|c|c|}
\hline Description of Series and Symbols & Source* & Unit & I 866 & I867 & 1868 & 1869 & 1870 & I $87 \mathrm{I}$ & 1872 \\
\hline I. Production of manuf. consumers' goods (Hoffmann)..... & W.A. I & $1907=426$ & 223 & 220 & 238 & 228 & 249 & 272 & 270 \\
\hline 2. Coal production........ & S.A. I & Mln. I907£ & 46 & 47 & 46 & 48 & 49 & 52 & 55 \\
\hline 3. Production of manuf. consumers' goods (our definition).. & See note & 66 & 520 & 510 & 550 & 530 & 570 & 620 & 620 \\
\hline 4. Production of agricultural products... & W.A. 2 & “ & I90 & I96 & 2 I 2 & 206 & $2 \mathrm{I} 4$ & 210 & 200 \\
\hline 5. Total production of consumers' goods $(3+4)$. & & “ & 710 & 706 & 762 & 736 & 784 & 830 & 820 \\
\hline 6. Imports of consumers' goods (ready for retail trade $f$ ) & Cf. text & “ & 100 & 100 & IIO & I IO & IIO & I 20 & 140 \\
\hline 7. Ixports of consumers' goods (on wholesale basis). & " & “ & 104 & 109 & II 5 & I 18 & I 24 & 138 & 146 \\
\hline 8. Consumption of consumers' goods $(5+6-7)$. & “ & “ & 706 & 697 & 757 & 728 & 770 & $8 \mathrm{I}_{2}$ & $8 \mathrm{I} 4$ \\
\hline 9. Retail price index. . & " & $=100$ & II 3 & II & I 7 & I I 3 & II 3 & $\mathrm{II}_{3}$ & I I \\
\hline I0. Value of consumption of consumers' goods $(8 \times 9: 100)$ & & Mln.£ & 797 & 830 & 886 & 822 & 870 & 918 & 968 \\
\hline I I. Consumption of services $\ldots \ldots \ldots \ldots \ldots \ldots \ldots$ & See note & Mln. I907£ & 263 & 266 & 269 & 270 & 273 & 278 & 282 \\
\hline I 2. Price index of services. & Cf. text & $1907=100$ & 70 & $7 \mathrm{I}$ & 7.3 & 76 & 78 & 80 & 82 \\
\hline I3. Value of consumption of services ( I I X I 2: 100) & & Mln. $\mathscr{E}$ & I 84 & 189 & 196 & 205 & $2 \mathrm{I}_{3}$ & 222 & 231 \\
\hline I4. Total value of consumption $(\mathrm{Io}+\mathrm{I} 3)$. & & & 980 & 1020 & 1080 & 1030 & 1080 & II 40 & I 200 \\
\hline I5. Total volume of consumption $(8+$ II $)$ & & Mln. I907£ & 970 & 960 & 1030 & 1000 & 1040 & rogo & I 100 \\
\hline I6. Total volume of production $(5+$ II $)$. & & & 970 & 970 & 1030 & IOIO & 1060 & IIIO & I 100 \\
\hline
\end{tabular}

\begin{tabular}{|c|c|c|c|c|c|c|c|c|c|c|c|c|c|c|c|c|c|c|c|c|c|}
\hline & 1873 & I 874 & 1875 & $\mathrm{r} 876$ & 1877 & 1878 & 1879 & 1880 & I88I & 1882 & I 883 & $188_{4}$ & I 885 & I 886 & I 887 & I 888 & I 889 & 1890 & $\mathrm{I} 89 \mathrm{I}$ & $\mathrm{I} 88_{92}$ & I893 \\
\hline I. & 284 & 292 & 284 & 282 & 287 & 272 & 254 & 301 & 293 & $3 \mathrm{II}$ & 317 & 322 & 301 & 304 & 316 & 334 & 349 & $35 \mathrm{I}$ & 364 & 340 & \\
\hline 2. & 57 & $5^{6}$ & 59 & 60 & 60 & 60 & 60 & 66 & 69 & 70 & 73 & 72 & $7 \mathrm{I}$ & $7 \mathrm{I}$ & 73 & 76 & 79 & $8 \mathrm{I}$ & 83 & $8 \mathrm{I}$ & \\
\hline 3. & 660 & 670 & 660 & 660 & 670 & 640 & 600 & 700 & 700 & 730 & $75^{\circ}$ & 760 & 7 IO & 720 & 750 & 790 & 820 & 830 & 860 & 810 & \\
\hline 4. & 209 & 226 & 228 & 217 & I99 & $2 \mathrm{I} 5$ & I 75 & $2 \mathrm{I} 4$ & 2 I 5 & 204 & 218 & 226 & 220 & 230 & 218 & 223 & 230 & 234 & 242 & 236 & 227 \\
\hline 5. & 869 & 896 & 888 & 877 & 869 & 855 & 775 & 9I4 & $9 \mathrm{I} 5$ & 934 & 968 & 986 & 930 & 950 & 968 & $\mathrm{IOI}_{3}$ & 1050 & 1064 & I 102 & 1046 & IOI \\
\hline 6. & I 50 & 150 & 160 & 170 & 170 & 180 & 190 & 200 & 190 & I 80 & 190 & 190 & 190 & I9o & 210 & 200 & 220 & 260 & 260 & 250 & 24 \\
\hline 7. & I 36 & I 39 & 138 & I 35 & 138 & I $3 \mathrm{I}$ & I 33 & $15^{2}$ & 162 & 156 & I6I & 165 & I6I & 170 & I 73 & 178 & I 79 & 180 & I 74 & 170 & \\
\hline 8. & 883 & 907 & 910 & 912 & $90 \mathrm{I}$ & 904 & 832 & 962 & 943 & $95^{8}$ & 997 & IOII & 959 & 970 & 1005 & I035 & IO9I & I I 44 & I I 88 & I I 26 & IOS \\
\hline 9. & I 20 & II 7 & I I 3 & I I I & I I 3 & I I I & 105 & 109 & 108 & 109 & 106 & 105 & IOI & 97 & 95 & 95 & 97 & 97 & 97 & 97 & \\
\hline o. & 1059 & $106 \mathrm{I}$ & 1029 & IOI 2 & rorg & 1002 & 874 & I049 & IOI9 & 1043 & $105^{8}$ & $106 \mathrm{I}$ & 969 & $94 \mathrm{I}$ & 955 & 985 & 1060 & I I IO & I I $5 \mathrm{I}$ & 1091 & 1039 \\
\hline I. & 287 & $29 \mathrm{I}$ & 295 & 299 & 301 & 305 & 306 & 3I I & 315 & 320 & 323 & 325 & 328 & $33 \mathrm{I}$ & 334 & 337 & $34 \mathrm{I}$ & 345 & $35^{\circ}$ & $35^{2}$ & $35^{6}$ \\
\hline 2. & 84 & 86 & 86 & 85 & 84 & 83 & 83 & 82 & 82 & 83 & 83 & 83 & 84 & 84 & 85 & 86 & 87 & 89 & 90 & $9 \mathrm{I}$ & \\
\hline 3. & $24 \mathrm{I}$ & $25^{\circ}$ & 254 & 254 & 253 & 253 & 254 & 255 & 258 & 266 & 268 & 270 & 276 & 278 & 284 & 290 & 297 & 307 & $3 I_{5}$ & 320 & 33 \\
\hline 4. & 1300 & I310 & I 280 & I 270 & 1270 & I 260 & II 30 & I 300 & I 280 & I3IO & I 330 & I 330 & I $25^{\circ}$ & I 220 & I 240 & I 280 & 1360 & 1420 & 1470 & I4IO & I 3 \\
\hline 5. & I I $\%$ & I 200 & I 210 & I 210 & I 200 & 1210 & I I 40 & I 270 & I 260 & I 280 & I 320 & I 340 & I 290 & 1300 & I 340 & 1370 & 1430 & I 490 & I 540 & 1480 & I 45 \\
\hline 6. & II 60 & 1190 & I I 80 & II 80 & 1170 & II60 & 1080 & I 230 & I 230 & I $25^{\circ}$ & I 290 & I3IO & I 260 & I 280 & I 300 & $135^{\circ}$ & I 390 & 1410 & $145^{\circ}$ & I 400 & I 370 \\
\hline
\end{tabular}

\begin{tabular}{|c|c|c|c|c|c|c|c|c|c|c|c|c|c|c|c|c|c|c|c|c|c|}
\hline & I 894 & I 895 & I 896 & 1897 & I 898 & I899 & I 900 & I $90 \mathrm{I}$ & 1902 & I9O3 & 1904 & I905 & I906 & I907 & I 908 & 1909 & I9ro & IgI I & IgI 2 & I9I3 & I914 \\
\hline I. & $35 \mathrm{I}$ & 370 & 380 & $3^{69}$ & 390 & $40 \mathrm{I}$ & 392 & 390 & 392 & 383 & 377 & 399 & 407 & 426 & 420 & $4 \mathrm{I} 3$ & $4 \mathrm{I} 6$ & 432 & 460 & 466 & 4 \\
\hline 2. & 84 & 85 & 87 & 90 & 90 & 98 & IOI & 98 & 102 & IO3 & IO4 & I06 & I I 2 & I 20 & I I 7 & II 8 & II 8 & I 22 & II 6 & I 29 & \\
\hline 3. & 840 & 870 & 900 & 880 & 920 & 960 & $95^{\circ}$ & 940 & $95^{\circ}$ & 930 & 920 & 970 & 1000 & 1050 & 1030 & 1020 & 1030 & 1060 & I I IO & I I 40 & 109 \\
\hline 4. & 233 & 232 & 234 & 229 & 239 & 235 & $23 \mathrm{I}$ & 237 & 246 & 227 & 242 & 246 & 248 & 250 & 258 & $26 \mathrm{I}$ & 256 & 250 & 246 & 246 & 25 \\
\hline 5. & 1073 & 1102 & I I 34 & I 109 & I I 59 & I I95 & II $8 I$ & I I 77 & I 196 & II 57 & II 62 & I 216 & I 248 & 1300 & I 288 & I $28 \mathrm{I}$ & I 286 & I310 & I 356 & I386 & I 34 \\
\hline 6. & 260 & 270 & 280 & 300 & 320 & 330 & 330 & $35^{\circ}$ & 340 & 340 & $35^{\circ}$ & 340 & 360 & 360 & 360 & $35^{\circ}$ & 360 & 370 & 370 & 400 & 3 \\
\hline 7. & 176 & 184 & I 88 & 180 & I 79 & 190 & I 8 I & I $8 \mathrm{I}$ & I 86 & I 88 & I97 & $2 \mathrm{II}$ & 222 & 234 & $2 \mathrm{II}$ & 224 & 234 & 245 & 254 & $25^{8}$ & 2. \\
\hline 8. & II 57 & II 88 & 1226 & I 229 & I 300 & I335 & 1330 & I 346 & $135^{\circ}$ & 1309 & I 3 I 5 & I 345 & I386 & $\mathrm{I} 426$ & I 437 & 1407 & I4I 2 & I 435 & 1472 & I 528 & $\mathrm{I}^{2}$ \\
\hline 9. & 93 & 9I & 89 & 93 & 93 & 93 & 95 & 96 & 97 & 97 & 97 & 97 & 97 & 100 & IOI & IOI & IOI & 103 & 105 & 105 & IC \\
\hline IO. & 1076 & 1080 & 1090 & I I4 I & I 210 & $\mathrm{I} 24 \mathrm{I}$ & 1262 & I $29 \mathrm{I}$ & I310 & I 270 & I 275 & 1305 & I 345 & $\mathrm{I}_{42} 6$ & $145^{\circ}$ & $\mathrm{I} 420$ & I 426 & I 479 & I 546 & I 603 & I6c \\
\hline I I. & 362 & 365 & $37 \mathrm{I}$ & 378 & 383 & 390 & 394 & 401 & 406 & $4 \mathrm{IO}$ & 4I 4 & 4I 8 & 425 & 430 & 435 & 436 & 443 & 447 & $45^{\circ}$ & 462 & 46 \\
\hline 12. & 94 & 95 & 95 & $9^{6}$ & 96 & $9^{6}$ & 96 & 97 & 97 & 98 & 98 & 99 & 100 & 100 & IOI & IOI & IOI & 102 & IO4 & Io & IO \\
\hline I3. & 340 & 347 & 353 & 363 & 368 & 374 & 378 & 389 & 394 & 402 & 406 & 4I4 & 425 & $43^{\circ}$ & 439 & 440 & 447 & $45^{6}$ & 468 & 490 & 5 \\
\hline 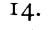 & $\mathrm{I} 420$ & 1430 & I 440 & I 500 & I 580 & 1020 & I640 & 1680 & I 700 & I 670 & I680 & 1720 & I 770 & I 860 & I 890 & I860 & 1870 & I940 & 2010 & 2090 & $2 \mathrm{I}$ \\
\hline I 5. & 520 & $155^{\circ}$ & 1600 & I610 & I 680 & $\mathrm{I} 73^{\circ}$ & 1720 & I $75^{\circ}$ & 1760 & 1720 & I 730 & I 760 & 1810 & I 860 & I 870 & I 840 & 1860 & I 880 & 1920 & 1990 & 190 \\
\hline I6. & I 440 & 1470 & 1510 & I 490 & I 540 & I 590 & I 580 & I 580 & 1600 & I 570 & I 580 & 1630 & I 670 & 1730 & I 720 & I 720 & I 730 & $\mathrm{I} 760$ & 1810 & $185^{\circ}$ & I $8 \mathrm{I}$ \\
\hline
\end{tabular}

* Source references. - W.A.I = W. Hoffmann, "Ein Index der industriellen Produktion für Grossbritannien seit dem I8. Jahrhundert," Weltwirtschaftliches Archiv, 40 (1934), p. 383

W.A.2 = L. Drescher, "Die Entwicklung der Agrarproduktion Grossbritanniens und Irlands seit Beginn des r. Jahrhunderts," Weltwirtschaftliches Archiv, $4 \mathrm{I}$ (1935), p. 270 .

$\dagger$ Brought on retail value basis by multiplication by the ratio $\frac{360}{220}$, derived from 1907 figures.

Note on calculation. Hoffmann's index of industrial production of consumers' goods excludes coal, which we consider as chiefly a consumers' good (following Cassel). Therefore coal production had to be included; both series have been converted to the base of roo7 pounds sterling (i.e., calculated at prices of 1907). For coal the 1907 value of production is I 20 million $£$; this is indicated by Hoffmann to be 14.9 per cent of total production, which therefore was $£ 804$ million; of this, 53 per cent, or $£ 426$ million, related to consumers' goods in the Hofiman sense. The total of series I and 2 has as its base 1050 for 1907, which is the retail value of consumers' goods production, according to Sir Alfred Flux (Census of Production I007, General Report, pp. 25-33). The I 907 figures for series 4, 6, 7, and II have been taken from the same source. The series for consumption of services (II) is composed of the following items (weights for I 1007 indicated in brackets, based on Flux's figures): (i) housing services, being the product of population and averace number of rooms available per head of population (weight: 230); (ii) number of passengers carried by railways (75); (iii) domestic services taken constantly at 80 , since the number of people engaged in these services is almust constant; (iv) number of passengers carried by tramways (I5); (v) letters delivered by postal service (30). For further particulars, see source references above and (for price indices, series 9 and I2 $_{2}$ ) text. 
To Hoffmann's index of industrial production of consumers' goods we first added coal production ${ }^{4}$ (which Hoffmann considered a producers' good) and then added production of agricultural products (Drescher's index), in

Chart i. - Indices of the Volume of Production of Manufactured Consumers' Goods (Unadjusted and Adjusted for Trend), in the United KingDom, AnNually, I866-I9I4*

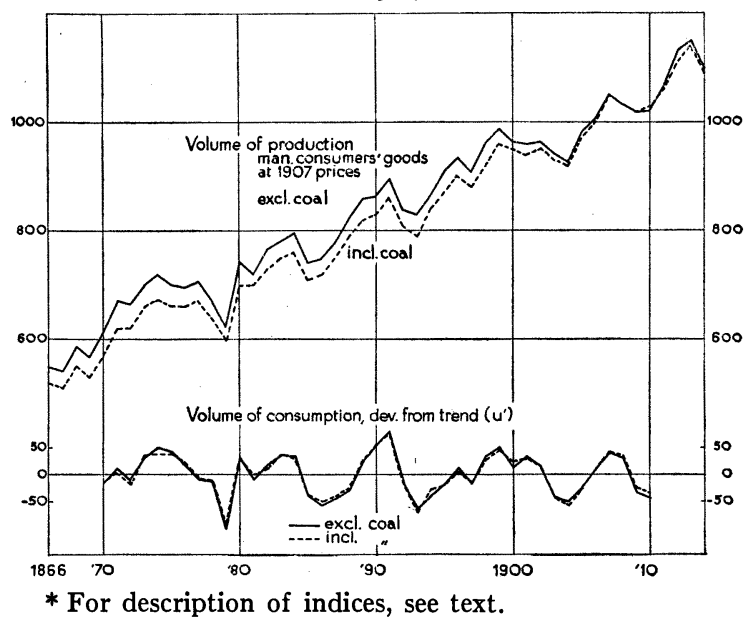

order to secure total production of consumers' goods. Next, imports of such goods were added and exports deducted, to obtain consumption of consumers' goods. (Here again additions to stocks are included.) Finally, an index of consumption of services was added. Separate price indices for goods and services were applied to the indices of the consumption of consumers' goods and the consumption of services in order to obtain value figures. Since all volume indices were expressed in 1907 pounds sterling - i.e., they were value indices at 1907 prices the price indices were taken with 1907 as a base. Various value figures for 1907 were obtained from Sir Alfred Flux's General Report on the I907 Census of Production (cf. note to Table I).

The index of agricultural production as given by Drescher ${ }^{5}$ covers about 78 per cent of total agricultural production in 1925 . The data for animal production are very rough, since they are based on figures for total live stock, of which a slowly changing percentage is assumed to be slaughtered each year.

\footnotetext{
${ }^{4}$ If coal production is not added, the course of the series is almost exactly the same. See Chart $I$.

${ }^{5} \mathrm{~L}$. Drescher, "Die Entwicklung der Agrarproduktion Grossbritanniens und Irlands seit Beginn des I9. Jahrhunderts," Weltwirtschaftliches Archiv, 4I (I935), p. 270.
}

The index of the imports of consumers' goods is based on goods ready for use and covers 69 per cent of these goods for 1907. This index, like the index of industrial production of consumers' goods, is based on retail value as given by Flux. The index for exports of consumers' goods covers 87 per cent of such exports in 1907. The index of consumption of services is explained in Table $\mathrm{I}$.

The index of retail prices is a combination of Colin Clark's index ${ }^{6}$ (for the trend movement) and Wood's index of retail prices ${ }^{7}$ (for the shorter fluctuations). Our index is the product of Wood's index and a smoothly moving cofactor; the cofactor is equal to the ratio between Clark's figures and Wood's figures for the middle of the periods for which Clark's figures are given (averages for cycles); between these midperiods, the cofactor has been linearly interpolated.

The index of service prices has been taken from Clark ${ }^{8}$ and linearly interpolated on the assumption that service prices move smoothly. For railway, tram, domestic, and postal services this assumption does not seem to be unreasonable; for rents, it is less certain; it is, however, also applied by Professor Bowley.?

\section{INCOME DATA}

Two kinds of incomes may be distinguished: wages and non-workers' income. For total wages in this study we have used Professor Bowley's estimate; ${ }^{10}$ and in order to estimate the fluctuations in other incomes, assessed incomes according to the income tax data, as corrected by Professor Bowley and Lord Stamp, have been taken as raw material. This material has, however, been adjusted somewhat further. (See Table 2.)

One reason for making adjustments was that Professor Bowley and Lord Stamp do not agree as to the timing of the series. Professor Bowley

\footnotetext{
${ }^{\circ}$ Colin Clark, National Income and Outlay (London, I937), p. 23 I.

"See George H. Wood, "Real Wages and the Standard of Comfort Since 1850," Journal of the Royal Statistical Society, LXXII (I909), pp. 94-95, 102-3.

${ }^{8} \mathrm{Op}$. cit.

${ }^{9}$ A. L. Bowley, Wages and Income in the United Kingdom since 1860 (Cambridge, England, I937), p. I2I.

${ }^{10}$ A. L. Bowley, Economic Journal, XIv (I904), p. 457, continued by A. C. Pigou, Industrial Fluctuations (London, I 927 ), p. 356 .
} 
Table 2. - Calculation of Non-Worker's Income

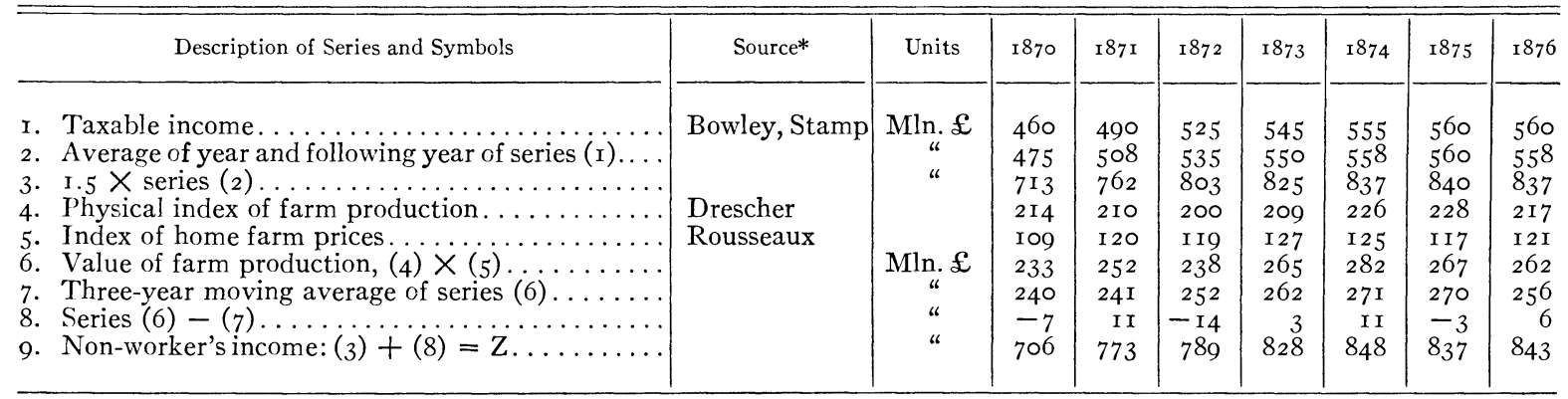

\begin{tabular}{|c|c|c|c|c|c|c|c|c|c|c|c|c|c|c|c|c|c|c|}
\hline & 1877 & I 878 & 1879 & I880 & I $88 \mathrm{I}$ & 1882 & $188_{3}$ & I 884 & I 885 & I 886 & 1887 & I 888 & I 889 & 1890 & $I 89 I$ & $189^{2}$ & I 893 & I 894 \\
\hline I. & 555 & 540 & 545 & 560 & 575 & 590 & 585 & 580 & 580 & $5^{80}$ & 595 & 615 & 640 & 640 & 635 & 625 & 630 & 645 \\
\hline 2. & 548 & 543 & 55 & 568 & $5^{83}$ & 588 & $5^{83}$ & 580 & 580 & 588 & 605 & 628 & 640 & $6_{3} 8$ & 630 & 628 & 638 & 653 \\
\hline 3. & 822 & 8 I 5 & 830 & 852 & 875 & 882 & 875 & 870 & 870 & 882 & 908 & $94^{2}$ & 960 & 957 & 945 & 942 & 957 & 980 \\
\hline 4. & I99 & 215 & I 75 & $2 \mathrm{I} 4$ & 215 & 204 & 218 & 226 & 220 & 230 & 21 8 & 223 & 230 & 234 & 242 & 236 & 227 & 233 \\
\hline 5. & I 20 & I I 5 & I I 3 & I I I & I IO & I I 2 & 109 & 100 & 92 & 87 & 86 & 92 & 86 & 94 & 93 & $9 \mathrm{I}$ & 87 & 82 \\
\hline 6. & 239 & 247 & I98 & 238 & 237 & 228 & 238 & 226 & 202 & 200 & 187 & 205 & I98 & 220 & 225 & 215 & I97 & I9 I \\
\hline 7. & 249 & 228 & 228 & 224 & 234 & 234 & 231 & 222 & 209 & 196 & I97 & 197 & 208 & 214 & 220 & 212 & $20 \mathrm{I}$ & I9I \\
\hline 8. & -10 & I9 & -30 & I4 & 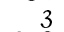 & -6 & 7 & 4 & -7 & 4 & -10 & 8 & -10 & 6 & 5 & 3 & -4 & $\circ$ \\
\hline 9. & 8I 2 & 834 & 800 & 866 & 878 & 876 & 882 & 874 & 863 & 886 & 898 & $95^{\circ}$ & $95^{\circ}$ & 963 & $95^{\circ}$ & 945 & 953 & 980 \\
\hline
\end{tabular}

\begin{tabular}{|c|c|c|c|c|c|c|c|c|c|c|c|c|c|c|c|c|c|c|}
\hline & I895 & I 896 & I 897 & I 898 & I899 & I900 & IgOI & 1902 & 1903 & I9O4 & 1905 & 1906 & I907 & 1908 & I9O9 & I9IO & IgI I & I9I 2 \\
\hline I. & 660 & 680 & 715 & 735 & 765 & 790 & 800 & 805 & 810 & 825 & 835 & 875 & 905 & 895 & 910 & 940 & 985 & 1055 \\
\hline 2. & 670 & 698 & 725 & $75^{\circ}$ & 778 & 795 & 803 & 808 & 818 & 830 & 855 & 890 & 900 & $9 \circ 3$ & 925 & $9^{6} 3$ & 1020 & . \\
\hline 3. & 1005 & IO47 & 1088 & I I 25 & II 67 & I I 93 & I 205 & I 2 I 2 & I 227 & I 245 & I 283 & I 335 & I 350 & I355 & I388 & I 445 & I 530 & \\
\hline 4. & 2.32 & 234 & 229 & 239 & 235 & $23 \mathrm{I}$ & 237 & 246 & 227 & 242 & 246 & 248 & $25^{\circ}$ & 258 & $26 \mathrm{I}$ & 256 & 250 & 246 \\
\hline 5. & 80 & 76 & 86 & 88 & 79 & 88 & 85 & 9I & 88 & 92 & 87 & 88 & 89 & 89 & 97 & 100 & 107 & 105 \\
\hline 6. & I 86 & I 78 & I97 & 210 & I 86 & 203 & 201 & 224 & 200 & 223 & 214 & 218 & 222 & 230 & 253 & 256 & 268 & $25^{8}$ \\
\hline 7. & 185 & 187 & I95 & I98 & 200 & I97 & 209 & 208 & 216 & 212 & 218 & 218 & 223 & 235 & 246 & 259 & $26 \mathrm{I}$ & $26 \mathrm{I}$ \\
\hline 8. & & -9 & 2 & I 2 & $-\mathrm{I} 4$ & 6 & -8 & I 6 & $-\mathrm{I} 6$ & I I & -4 & $\circ$ & $-I$ & -5 & -7 & -3 & -7 & -3 \\
\hline 9. & 1006 & I038 & I090 & I I 37 & I I 53 & I I 99 & I I97 & I 228 & I 2 I I & I $25^{6}$ & I 279 & I335 & I349 & I $35^{\circ}$ & I 395 & I 442 & I 537 & $\cdots$ \\
\hline
\end{tabular}

* Source references. - Bowley, Stamp: Figures from Bowley (Economic Journal, I904) as given by Sir W. Layton, An Introduction to the Study of Pric (Lonlon, I020), p. I87, supplemented by figures from Lord Stamp, British Incomes and Property (London, I9I6), p. 3 I9, converted to a comparable basis

Drescher: cf. Table I (W.A.2).

Note on calculation. Starting from taxable incomes, we have corrected these figures first, for timing (see below) by taking two-year averages; second, $\mathrm{f}$ the smoothing effect of (a) these two year-averages and (b) the three-year moving averages prescribed by tax laws and for the fact that low incomes are nc taxed, by multiplying by r.5 (cf. text). The correction for smoothing would, however, be sufficient only if all incomes show only eight-year cycles. This approximately true for most incomes, but in addition agriculture presumably shows short erratic fluctuations, due to crop fluctuations or price fluctuation which are almost entirely absent in rent figures, upon which the income estimates for farmers are based, according to tax regulations. Therefore, an estima 1 is made of farm income by multiplying Rousseaux' price index of home farm products by a physical index of farm production, converted to such a basis $₹$ to yield a product of these two series equal to 222 in 1907 , which is the value of farm production according to Sir Alfred Flux (cf. Table I). Deviations fros three-year moving averages of this series are added to the estimates (3) already obtained. It may be remarked at once that a further correlation analys sugests that fluct ations in non-w

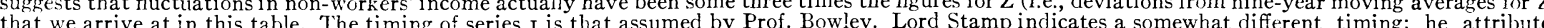
that we arrive at in this table. The timing of series $\mathrm{I}$ is that assumed by Prof. Bow!ey. Lord Stamp indicates a somewhat different timing; he attribut the same figures to a period half a year earlier. "The assessed profits for the year ending 5 th April, Igc9, may be taken to be actual profits for the year to th beginning of June I907, in times of normal and regular increase" (British Income and Property, I9I6 edition, p. I78). Hence the average of two years he been taken (second line of table). Since this calculation of the lag does not take account of (a) businesses set up during the year of assessment, of (b) th possibility of reporting losses at once [cf. H. B. Spaulding, The Income Tax in Great Britain and the United States (London, I927), pp. 2I8-I9], and (c) so-calle "I3.3rd section," permitting a more recent moving average in some cases of declining profits [cf. Lord Stamp, The National Capital and Other Statistical Studi what behind our series (cf. text). According to private information obtained from Lord Stamp, the effect of provision (b) on the statistical figures has not bee what beh.

considers that the figure for the year of assessment I908-09 corresponds to incomes earned in $1907 ;{ }^{11}$ Lord Stamp indicates the year ending June, I907 as the corresponding income period. To begin with, we have followed Lord Stamp and have taken the two-year average of above.
Professor Bowley's figures for 1907 and I90. to represent the 1907 income.

This series has been multiplied by $\mathrm{I} .5$, sinc for three reasons its fluctuations are, withou doubt, too small: First, assessed incomes are for most types of incomes, a three-year movin average. Secondly, we have already taken two-year moving average. On the assumptio. 
that the fluctuations are eight-year period sine curves, it is easily computed that the original fluctuations have been reduced by about onesixth. Thirdly, some incomes are below the exemption limit. An estimate of these low incomes has been made by several authors, for various years. ${ }^{12}$ On the average they amount to about one-quarter of assessed incomes. In summa, multiplication by $\frac{5}{4} \times \frac{6}{5}$, or $\mathrm{I} \cdot 5$, is therefore needed. This factor is correct only for the fluctuations of the series around its trend; it need not be correct for the trend values themselves. Because of the arguments used, these values should be multiplied by only 1.25 . For other reasons a multiplication by $\mathrm{I} .5$ for the trend values also seems appropriate; but these reasons need not occupy us now since we are interested in the deviations only. ${ }^{13}$

One component of income fluctuations is not included in income tax figures, viz., the short fluctuations in agricultural incomes. Farmers are taxed in proportion to rents, and rents change slowly because of the long duration of the contracts. In the long run, rents will follow agricultural profits more or less, but certainly not in the short run. We have, therefore, added the deviations from three-year moving averages of the value of farm production. This value was estimated in the following way: An index for the volume of farm production calculated by Drescher ${ }^{14}$ was multiplied by an index of prices for home farm products calculated by Rousseaux. ${ }^{15}$ The value of the product for 1907 was estimated by use of the figures mentioned by Flux in the General Report on the 1907 Census. Although this method is a rough one - Drescher's index is unsatisfactory as far as the production of meat is concerned, in particular - the estimate of agricultural income thus secured seemed better than no estimate whatsoever.

The final figures obtained are tabulated in line 9 of Table 2 . We have tried to test these figures with independent figures from other

\footnotetext{
${ }^{12} \mathrm{Cf}$. Stamp, British Incomes and Property (London, IgI6), p. 427, where a number of estimates have been reproduced.

${ }^{13}$ Another question remains, viz., whether there are not other reasons for assuming that the income fluctuations as reported by assessments are too weak. Cf. below.

${ }^{14}$ Op. cit.

${ }^{15} \mathrm{P}$. Rousseaux, Les monvements de fond de l'économie anglaise, I800-1913 (Bruxelles, 1938), pp. 264-65.
}

sources. Limitations of space prevent us from giving all the details of this test; ${ }^{16}$ briefly, however, we have attempted to reconstruct non-labor income from data on production, prices, international trade, and wages. The comparison does not prove to be very satisfactory unless it is assumed that (I) Professor Bowley's timing is correct; (2) raw material cost is calculated at lagged prices (prices at moment of purchase instead of prices at moment of delivery of production); and (3) the fluctuations in actual incomes are about three times as large as those given in Table 2. From all series calculated the trends have been eliminated by using deviations from nine-year moving averages.

\section{RELATIONS BETWEEN INCOMES AND CONSUMPTION TESTED}

In accordance with general economic theory, we have assumed that consumption outlay, $U^{\prime}$, depends, first of all, on total wages, $L$, nonlabor income, $Z$, and cost of living, $p$. Since our figures for consumption also include additions to stocks, one or two factors explaining these additions have been included. From another investigation $^{17}$ that we made on this subject, we felt justified in including the following factors:

(I) the rate of increase in the volume of consumption: $u_{t}^{\prime}-u_{t-1}^{\prime}$

(2) the interest rate, $m^{s}$.

Our previous investigations led us to believe, however, that the influence of $m^{s}$ would be very small.

For the timing of the explanatory series, we assumed that wages are spent without much delay. For the case of non-workers, the possibility of a lag between incomes earned and consumption outlay had to be recognized. A lag may occur for various reasons: First, these incomes can often be disposed of only at a time period later than that of earning. Secondly, even if they are disposed of at the moment of earning (shopkeepers, e.g.) their exact magnitude is determined later (after the closing of

\footnotetext{
${ }^{16}$ A number of these details are treated in my forthcoming book, Business Cycles in the United Kingdom, 1870-1914. 17 "An Acceleration Principle for Holding Stocks," to be pubiished in Studies in Mathematical Economics and Econometrics: Henry Schultz Memorial Volume.
} 
the books), and, therefore, that magnitude can influence outlay only at a later moment. Thirdly, the effect of the knowledge that one's income has risen or fallen on one's consumption outlay may also take place only after some time - the duration of the psychological reaction. The less the pressure of income forces one to react immediately to changes, the longer that reaction may take. Finally, income payments (e.g., dividends) as well as some types of consumption outlay (travel expenses, Christmas presents) show seasonal fluctuations.

Since the lag cannot be fixed beforehand, a test of the relation with a fixed $a$ priori value of that lag did not seem adequate; we, therefore, based our test on a not a priori restricted statistical estimate of lag. This estimate may be obtained most easily by the inclusion of two different values of $Z-$ e.g., for $t$ and $t-$ I. If the lag is between $\circ$ and $\mathrm{I}$, the coefficients for $Z_{t}$ and $Z_{t-1}$ will both be positive; if it is more than I, the coefficient for $Z_{t-1}$ will be positive and that for $Z_{t}$ negative. It is appropriate then to try $Z_{t-1}$ and $Z_{t-2}$; if both coefficients are positive, the lag lies between $\mathrm{I}$ and 2 ; and so on. Graphical trials may shorten this process of adaptation; in the present case, it proved to be appropriate to include $Z_{t-1}$ and $Z_{t-2}$.

In the case of $p$, an influence without delay could reasonably be expected, since the amount to be paid depends on the level of actual prices in a direct way. But a lagged influence could also be imagined to exist; decisions based on earlier prices may contribute to the actual behavior of the consumer. For that reason $p_{t-1}$ was also included in some of the calculations.

In summary: attempts have been made to explain the fluctuations in consumption outlay by a linear combination of the fluctuations in total wages $\left(L_{t}\right)$, non-labor income with lags of $\mathrm{I}$ and 2 years $\left(Z_{t-1}\right.$ and $\left.Z_{t-2}\right)$, price level $p_{t}$, and rate of increase in quantity of consumption $\left(u_{t}-u_{t-1}\right)$; and in additional attempts the price level with a lag of I year $\left(p_{t-1}\right)$ and the interest rate $\left(m^{*}\right)$ have been added.

Unfortunately, the correlation between $L$ and $Z_{t-1}$ appears to be high, which makes accurate determination of the coefficients for both these variables impossible. One coefficient has to be determined on a priori grounds. We have chosen that for $L$, at 0.8 ; various investigations point to about that value for the marginal propensity to consume for workers' families. ${ }^{18}$

The two factors $p_{t-1}$ and $m^{s}$ appeared to have only very subordinate influence; therefore, they were not included in the final equation. With the remaining variables, the best result obtained was

$$
\begin{aligned}
U_{t}^{\prime} & =0.80 L+0.50 Z_{-1}+0.42 Z_{-2}+\mathrm{I} \text { I. } 7 p \\
& +0.45\left(u_{t}-u_{t-1}\right) .
\end{aligned}
$$

(See Chart 2.)

Chart 2. - Estimates of Consumption Outlay in the United Kingdom, Annually, I874-1910*

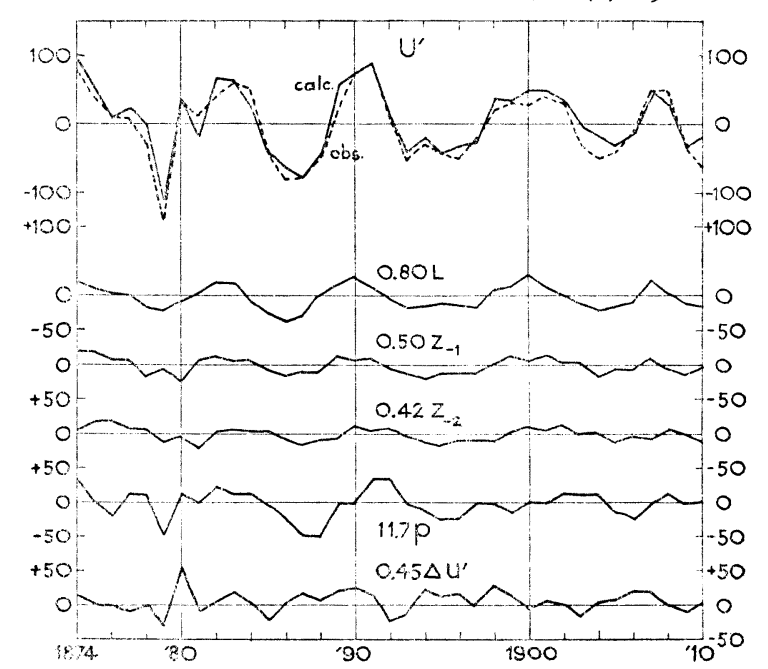

* For description of series, see text.

\section{SIGNIFICANCE OF RESULTS}

The significance of the free coefficients (i.e., all except that for $L$ ) was tested in various ways. One way was the rather elementary method of trying alternatives, as follows:

I. The regression coefficient for $L$ was varied and values of 0.9 and 0.7 were tried.

2. As has been mentioned already, $m^{s}$, the rate of interest, and $p_{-1}$, cost of living one year before, were included as additional variables.

${ }^{18}$ For the United States, cf. my Business Cycles in the United States, 1919-1932 (Geneva, 1939), pp. 36-37, where the figures 0.83 and 0.95 are mentioned. For Holland, cf. J. Tinbergen and A. L. G. M. Rombouts, "Statistische meting van Keynes' begrippen 'propensity to consume' en 'propensity to save' voor Nederland," De Nederlandsche Conjunctuur, xI (1940), p. 21 , where a figure of 0.8 is found. It would seem that English workers are more like Dutch than like American workers, in that they will save more in good times and dissave in bad times. 
All calculations show the same order of magnitude for the coefficients (Table 3 ). Those for $p$ and $u-u_{-1}$ are particularly stable. Those for $Z_{-1}$ and $Z_{-2}$ are less stable, but always positive. This means that the lag of the $Z$-term is always between one and two years or, taking account of what has been said about the timing of $Z$, that the lag in the influence of non-labor income on consumption is between one-half and one and one-half years.

Table 3.- Some Results of Alternative CalculaTIONS (I874-I9IO)

\begin{tabular}{|c|c|c|c|c|c|c|c|c|}
\hline \multirow{2}{*}{ No. } & \multicolumn{7}{|c|}{ REGRESSION COEFFICIENTS FOR TERMS WITH: } & \multirow{2}{*}{$\begin{array}{l}\text { Corr. } \\
\text { coeff. }\end{array}$} \\
\hline & $L^{*}$ & $Z_{-1}$ & $Z_{-2}$ & $p$ & $u-u-1$ & $p_{-1}$ & $m^{4}$ & \\
\hline I & 0.8 & 0.50 & 0.42 & II.7 & 0.45 & . & . . & 0.922 \\
\hline 2 & 0.9 & 0.44 & $0.4 \mathrm{I}$ & I I. 4 & 0.44 & $\ldots$ & . . & 0.915 \\
\hline 3 & 0.7 & $0.5^{6}$ & 0.43 & I I. 8 & 0.47 & . & . & 0.925 \\
\hline 4 & 0.8 & $0.46 \dagger$ & $0.46 \dagger$ & II. 5 & 0.46 & 0.0 & . & 0.921 \\
\hline 5 & 0.8 & $0.48 \dagger$ & $0.48 \dagger$ & II. 4 & 0.47 & . & I. 63 & 0.935 \\
\hline
\end{tabular}

* This coeificient has been given a priori.

$\dagger$ In these cases, the coefficients for $Z_{-1}$ and $Z_{-2}$ have, for convenience, been chosen equal.

A second elementary test of the significance of the regression coefficients consisted in the splitting up of the period into two subperiods, and the establishment of a regression equation for each subperiod. The results are given in Table 4. Again, not much variation is evident in the order of magnitude of the coefficients.

Taele 4. - Results for Two Subperiods

\begin{tabular}{|c|c|c|c|c|c|c|c|c|c|}
\hline \multirow{2}{*}{ No. } & \multirow{2}{*}{ Period } & \multicolumn{7}{|c|}{$\begin{array}{l}\text { REGRESSION COEFFICIENTS FOR TERMS } \\
\text { WITH: }\end{array}$} & \multirow{2}{*}{$\begin{array}{l}\text { Corr. } \\
\text { coeffi. }\end{array}$} \\
\hline & & $L^{*}$ & $Z_{-1}$ & $Z_{-2}$ & $p$ & $u-u_{-1}$ & $p-1$ & $m^{\mathrm{s}}$ & \\
\hline I & I874-1010 & 0.8 & 0.50 & 0.42 & I I. 7 & 0.45 & $\ldots$ & $\ldots$ & 0.922 \\
\hline 6 & I $874^{-I} 895$ & 0.8 & 0.35 & 0.68 & 9.0 & 0.55 & $\ldots$ & $\ldots$ & 0.950 \\
\hline 7 & I 896-I910 & 0.8 & 0.42 & 0.73 & 8.4 & 0.55 & . & . & 0.826 \\
\hline 2 & I $874^{- \text {I9 }}$ Io & 0.9 & 0.44 & $0.4 \mathrm{I}$ & I I.4 & 0.44 & . & . & $0.9 I_{5}$ \\
\hline 8 & I $874-1895$ & 0.9 & 0.44 & 0.30 & I 2.6 & 0.42 & . & . & $0.94 \mathrm{I}$ \\
\hline 9 & I896-I910 & 0.9 & 0.49 & 0.29 & I 3.0 & 0.43 & $\ldots$ & . & $0.82 \mathrm{I}$ \\
\hline
\end{tabular}

* The coefficient for $L$ has been chosen a priori.

A third test was made along the lines of R. A. Fisher's methods. The assumptions made by Fisher are (i) that there are no error components in the explanatory variables, but only in the variable to be explained, (ii) that the error component in the latter is a sample from a normal universe, and (iii) that that sample is a random one. We think assumption (i) is approximately fulfilled, since the errors of measurement are far less important than the errors made by the use of an incomplete theory. As to assumption (ii), the distribution of the residuals was compared with a binomial distribution for $n=10$, and the $\chi^{2}$-test applied. The probability of the deviations found appeared to be $P=0.80$, which is quite satisfactory. Assumption (iii) was tested by the determination of the serial correlation of the residuals; this appears to be $-0.05 \pm 0.17$, which is also satisfactory. The assumptions

Chart 3.-Tests of Free Coefficients, by Use of BUNCH MaP

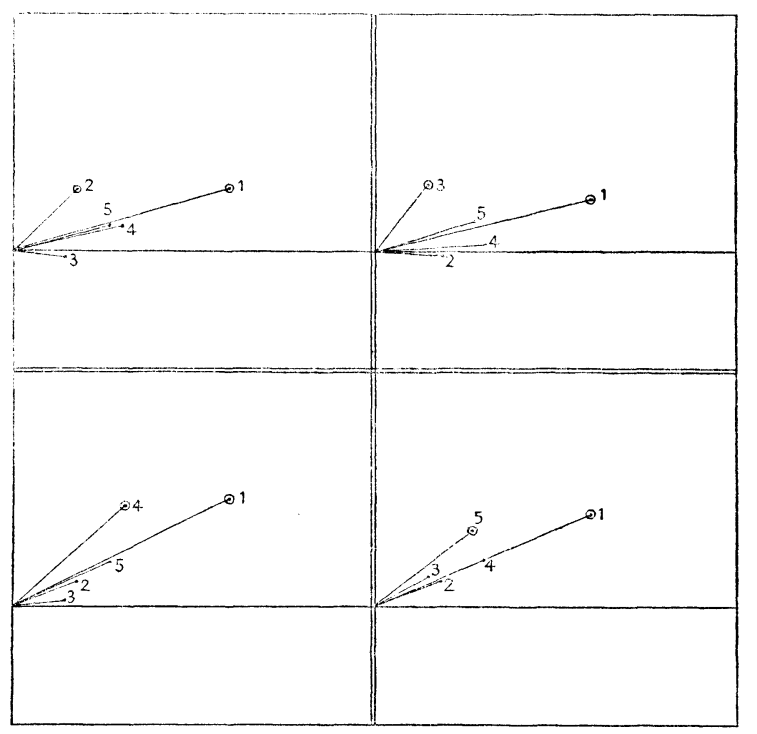

upon which Fisher's method is based are, therefore, fulfilled. Calculation of the standard deviations of the regression coefficients yields:

$\begin{array}{rrrrr}\text { Explanatory variable } \ldots \ldots \ldots & Z_{-1} & Z_{-2} & p & u-u_{-1} \\ \text { Regression coefficient } \ldots \ldots \ldots & 0.50 & 0.42 & \text { II.7 } & 0.45 \\ \text { Standard deviation of regression } & & & & \\ \text { coefficient } \ldots \ldots \ldots \ldots \ldots \ldots & 0.13 & 0.15 & 1.83 & 0.07\end{array}$

These results are in accordance with the results already mentioned: the coefficients for $p$ and $u-u_{-1}$ are very stable, those for $Z_{-1}$ and $Z_{-2}$ less stable, but it is very improbable that they are not both positive. Of course, we should rot forget that the coefficient for $L$ has been assumed as given beforehand. We do not think, however, that this invalidates this conclusion very much. A glance at Table 3 shows 
that a change of $0 . \mathrm{I}$ in the regression coefficient for $L$ has not a very great influence on the other regression coefficients.

A fourth test, finally, was made by the construction of a bunch map. Here again the coefficient for $L$ was taken at its a priori value o.8. The spread in the bunches is not ideal; but again the coefficients for $p$ and $u-u_{-1}$ are, according to this test, the most stable ones, whereas those for $Z_{-1}$ and $Z_{-2}$ are, practically speaking, positive. Only one of the beams shows a slope slightly below zero (cf. Chart 3, which gives only the I2345-set).

\section{CONCLUSIONS}

The chief conclusion to be drawn from our results concerns the theme of this paper, viz., the lag between income and consumption outlay. Since the regression coefficients for both the $Z_{-1}$-term and the $Z_{-2}$-term are positive, the average lag must be between one-half and one and one-half years, with the most probable value at about one year. Thus our results suggest an average lag of one year between nonlabor incomes and consumption outlay. This lag is of great importance for the explanation of the business cycle. ${ }^{19}$ We have tried to find confirmation of this result in the behavior of consumption figures for separate commodities and we have succeeded. Consumption of sugar as well as of coffee, tea, spirits, and cotton manufactures all show the same feature.

A second conclusion may be drawn from our equation, viz., from the regression coefficient for $p$. In principle this coefficient would enable us to calculate some sort of average elasticity of demand for consumers' goods. Given the average values of consumption outlay ( 1500 ) and of the price level (99), we find that the elasticity of outlay with respect to prices is 0.78 . It follows that the elasticity of quantity de-

${ }^{19} \mathrm{Cf}$. Business Cycles in the United Kingdom, I870-19I4, where this thesis will be considered in detail.

RotTerdam SCHOOL OF ECONOMICS

RotTERDAM, Holland manded with respect to prices is $0.78-\mathrm{I}=$ -0.22 . This is a low figure, contrary to what is often assumed. In order to test this result too, we have calculated the elasticity of demand of some individual commodities. The results were

\begin{tabular}{|c|c|}
\hline Sugar & 0.06 \\
\hline Coffee & 0.0 \\
\hline Tea & \\
\hline Spirits & 0. \\
\hline Cotton manufactures & 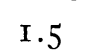 \\
\hline
\end{tabular}

Although this small sample cannot prove very much, it is not in contradiction to the general result; four out of five elasticities are very low indeed.

Even a third conclusion may be drawn, but with still more caution. It concerns the marginal propensity to consume for non-workers. If our income figures were exact, the sum total of the two regression coefficients -0.50 and 0.42 , or 0.92 - would indicate that marginal propensity. Since, however, our test of the income figures (cf. above, p. 5) suggests that our series underestimates by about three times the intensity of the income fluctuations, the marginal propensity should accordingly be taken at onethird of the above value, or $0.3 \mathrm{I}$, which might seem too low. One fact must not be forgotten when judging this figure: Incomes include undistributed profits, of which nothing is consumed but all saved. And the English consumer probably is conservative. Nevertheless, the figure is low; and the question remains whether it may be due partly to the low quality of our statistics. Only fresh material could help us answer this question.

Summarizing our results very briefly, we are led to believe that for the United Kingdom, I870-I9 I4, consumption outlay of non-workers lags about one year behind the corresponding incomes; and the elasticity of demand as a whole and the marginal propensity to consume seem to be very low figures.

J. Tinbergen 
http://www.jstor.org

\title{
LINKED CITATIONS \\ - Page 1 of 1 -
}

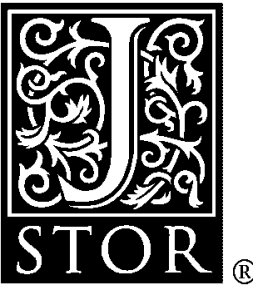

You have printed the following article:

\section{Does Consumption Lag Behind Incomes?}

J. Tinbergen

The Review of Economic Statistics, Vol. 24, No. 1. (Feb., 1942), pp. 1-8.

Stable URL:

http://links.jstor.org/sici?sici=0034-6535\%28194202\%2924\%3A1\%3C1\%3ADCLBI\%3E2.0.CO\%3B2-5

This article references the following linked citations. If you are trying to access articles from an off-campus location, you may be required to first logon via your library web site to access JSTOR. Please visit your library's website or contact a librarian to learn about options for remote access to JSTOR.

\section{[Footnotes]}

\author{
${ }^{7}$ Real Wages and the Standard of Comfort since 1850 \\ George H. Wood \\ Journal of the Royal Statistical Society, Vol. 72, No. 1. (Mar., 1909), pp. 91-103. \\ Stable URL: \\ http://links.jstor.org/sici?sici=0952-8385\%28190903\%2972\%3A1\%3C91\%3ARWATSO\%3E2.0.CO\%3B2-H \\ ${ }^{8}$ Real Wages and the Standard of Comfort since 1850 \\ George H. Wood \\ Journal of the Royal Statistical Society, Vol. 72, No. 1. (Mar., 1909), pp. 91-103. \\ Stable URL: \\ http://links.jstor.org/sici?sici=0952-8385\%28190903\%2972\%3A1\%3C91\%3ARWATSO\%3E2.0.CO\%3B2-H \\ ${ }^{10}$ Tests of National Progress \\ A. L. Bowley \\ The Economic Journal, Vol. 14, No. 55. (Sep., 1904), pp. 457-465. \\ Stable URL: \\ http://links.jstor.org/sici?sici=0013-0133\%28190409\%2914\%3A55\%3C457\%3ATONP\%3E2.0.CO\%3B2-L
}

NOTE: The reference numbering from the original has been maintained in this citation list. 